\title{
Impact of Multimedia-Based Off-Line Learning on Student Motivation and Outcomes
}

\author{
Albinus Silalahi ${ }^{1}$, Wesly Hutabarat ${ }^{1}$, Simson Tarigan $^{1} \&$ Yogi Chandra ${ }^{2}$ \\ ${ }^{1}$ Department of Chemistry, Faculty of Mahematics and Basic Scince, State University of Medan, Medan, \\ Indonesia \\ ${ }^{2}$ Postgraduate Programs, State Universiity of Medan, Medan, Indonesia \\ Correspondence: Wesly Hutabarat, Department of Chemistry, Faculty of Mahematics and Basic Scince, State \\ University of Medan, Medan, Indonesia.
}

Received: September 20, 2018

Accepted: October 11, $2018 \quad$ Online Published: October 22, 2018

doi:10.20849/ajsss.v3i4.471

URL: https://doi.org/10.20849/ajsss.v3i4.471

\begin{abstract}
Investigation of the impact multimedia-based off-line learning towards student motivation and outcomes was carried out based on ADDIE model, and the 2013 vocational high school curriculum content standards. It was found that the implementation of the multimedia was highly usefull as a learning device. The population of this study were students of grade XI of a vocational high school 1 in Percut Sei Tuan, Medan Indonesia. The sample selected was 2 classes of the grade XI and classified into experimental and controlled groups which consisted of 36 students respectively. The experimental group was taught by the MAOL and the controlled group taught by web-based adobe flash-based instruction (WAFI) learning approaches. Instruments used to collect data student motivation and outcomes were questionnaires and achievement tests respectively. The Data collected were analyzed with SPSS softwares. The results showed that the student motivation and achievements of the experimental group were significantly higher than the controlled group on the subject of acid and base solutions, with a significance level of $5 \%$ (with the criteria of $\mathrm{Sig}<\alpha$ value is $0.001<0.05$ ) ; Furthermore, there was a positive correlation between motivation and student outcomes at a significance level of $5 \%$.
\end{abstract}

Keywords: learning motivation, multimedia-based offline learning, student outcomes, web-based online learnig

\section{Introduction}

The introduction of school-based management into Indonesian educational system since 2001, has made it possible for Indonesian government to facilitate schools with internet facilities and introduced the new information and technology webs into educational system throughout the country in elementary and higher educational levels.

Teachers' skills and perspectives have a great influence on the implementation of multimedia in their classrooms, it depends on their ability to use the IT into classrooms to support teaching and learning process (Jantjies \& Joy, 2015). It was also known that in many countries teachers have made a great effort to integrate the IT to support teaching and learning processes, but a number of teachers were unable to do so, which may due to a number of factors, such as lack teacher expertise and lack of technology facilities and infrastructure to enabling them to integrate the learning materials with the IT learning technology (Bitner \& Bitner, 2002). Although, the schools have been provided with internet facilities, science teachers continue to carry out teaching and learning process by merely using textbooks without introducing the internet into classroom and science investigation was carried out by implementing teacher's lab "guided book" where students were asked to follow directions and meet the textbook objectives (Trumbull, Scarano \& Bonney, 2006:1718). It was known that the usage of the "guided book" in science education could results in the lack of student autonomy due to the fact that the science "guided book" still dominated by teachers and found that questioning skills could be used to enhance greater student autonomy in science investigations (Ramnarain, 2011). Therefore, it needs to increase student motivation in classroom and labs activity by introducing the new information technology of the internets into the educational system i.e. by the introduction of multimedia.

The introduction of the new technology into educational system had made it possible for teachers to download new information concerning with learning materials and teaching strategies using multimedia and learning 
management system with virtual learning.

Today, information and technology (IT) has been widely used around the world for teaching and learning processes (Sylvestre,Haiyan \& Yiyi, 2018), and it was found that the IT could be used to facilitate multilingual teaching and learning process, but a number of teachers were unable to use the technology due to their lack of knowledges in IT usage (Jantjies \& Joy, 2015).

The use of multimedia in classrooms can help students to study learning materials effectively and stimulate them in solving problems (Anwariningsih \& Ernawati, 2013). However, the usage of multimedia in chemistry learning has not been introduced widely into Indonesian education sytems, especially multimedia-based adobe flash-based off-line learning (MAOL). The useage of multimedia learning into Indonesian educational system is generally based on cognitive theory of multimedia learning, that is, a theory which introduces learning materials in words and pictures, based on the assumption that people processing verbal or words and visual materials or pictures separately (dual-channels assumption), each channel can process only a certain amount of material at a time (limited capacity assumption), and meaningful learning can be achieved when people engages in an appropriate cognitive learning process (active-processing assumption) of filtering, selecting, organizing, and integrating information (Mayer, 2002). This assumption can be seen as a fundamental basic in applying multimedia into educational system.

According to multimedia principles student learns words and pictures faster and clearly than words alone (Mayer, 2002). However, by adding word into picture arbitrarily is not an effective strategy to create a good multimedia learning. Therefore, it needs to create a multimedia learning based on human mind works based on Mayers' cognitive theory of multimedia learning, i.e. when using multimedia as a learning tool we must consider the following assumption: 1). Pupils process information by two separate ways which is called auditory and visual coding 2). It has a limited capacity and 3). Mastery learning is achieved when pupils are actively processing, filtering, organizing, and incorporating incoming new information into their previous knowledge (Mayer, 2002).

People can only process a finite amount of information at a time, and they make sense of incoming new information by actively creating mental representations. Mayer also emphasized the important role of human memory stores in multimedia learning strategy, i.e. sensory memory (receives and stores stimuli temporarily), working memory (processes information and incorporates into previous knowledge to create new constructs), and long-term memory (stores all subjects learned).

According to Mayer's multimedia learning theory, it is believed that human brain does not consider words, pictures, and auditory information presented as a mutually exclusive, rather, they are picked up and organized dynamically to result in logical mental constructs. He emphasized the importance of learning based on contents which can transfer knowledge successfully when new information is incorporated into previous knowledge.

According to Dale (1969) the use of instructional media is not determined by how sophisticated and modern the tools the teacher provides. It is considered as the suitability of the media with the subject taught. It is possible that the teacher taught the subjects without using learning sophisticated media, because the learning material is simple, so that the teacher explains the subjects orally. Generally, chemistry learning material consists of abstract concepts (Kozma \& Russell, 1979; Wu, 2003), therefore many students find it difficult to comprehend the subjects (Othman, Treagust \& Chandrasegaran, 2008), because they only memorize chemical concepts for granted without logically comprehence (Niaz \& Rodriguez, 2000).

It is presumed that the multimedia can be used to overcome this shortage, because it can visualize and animate the concepts into a reasonable and real life. As we know that multimedia is a combination of several media such as text, graphics, audio and video integrated with computer (Anleigh \& Thakar, 1997), so that the media can be used to motivate students and enhance student outcomes. It was also found that teachers have a positive attitude in using internet technogy into classrooms (Ziad, 2016).

The adobe flash plyer-9 program used in this study is a Macromedia commercial application, which is used to create vectorial animations. Many companies have web pages containing animations created with Adobe Flash, due to its ability to develope vectorial images as well as interactive learning (Garcia, Quiros, Santos, Gonzalez \& Fernanz, 2007). In general the adobe flash programs have advantages compared to other programs, namely: (1) able to create interactive buttons; (2) capable of making video color images (3) able to make the transformation of animation into another form and able to make live animation (4) the file can be converted to application files (exe); and (5) display a wide range of images (Salim \&Tiawa, 2014).

The development and usage of the Adobe Flash program-based off-line chemistry learning would make students being interested in, because the Adobe Flash introduces unique animations, so that students are motivated and 
actively involved in teaching and learning activities. Therefore, the development of the Adobe Flash-based off-line chemistry learning based on the Indonesian National Curriculum is expected to improve students' motivation and learning outcomes.

The work investigated attempts to address a main research question: Does the use of multimedia-based off-line make any difference to student's motivation and outcomes?

\subsection{Objective of the Study}

The objective of the study was to find out the impact of the multimedia adobe-flash off line (MAOL) learning on student motivation and achievements, especially in learning acid and basic solutions.

\section{Literature Review}

\subsection{Student Achievements}

Student achievement is defined as student behavioral changes as a result of their interaction with the environtment (Skourdoumbis, 2014). The main objective of the development and usage of the learning media are to motivate, stimulate and assist students in masterying the subject, in order to improve learning outcomes because people processing verbal or words and visual materials or pictures separately, in which a certain amount of material can be processed at a certain time and as a result meaningful learning can be achieved when they engage in an appropriate cognitive learning process by filtering, selecting, organizing, and integrating incoming information (Mayer, 2002).

One of the appropriate learning media that can be developed to support chemistry learning is the Adobe Flash Player-based off-line learning media program which was designed to meet the Indonesian National Curriculum. Anjarwati, Winarno and Churiyah (2016) found that the development and usage of the Adobe Flash Professional-based learning media can increase student learning outcomes.

As we know that multimedia applications have greatly infiltrated into education system. They allow teachers a great possibility to demonstrate and visualize the subject matter more clearly and comprehensibly, as well as enabling them to prepare learning material for students to optimize their learning activities (Milkova, 2015). In line with this finding, it was also found that there was a significant relationship between students' use of multimedia learning and their achievements (Al-Hariri \& Al-Hattami, 2017). It was also found that multimedia strategies effectively increased student's achievements in the primary and pre-school levels. Therefore, the teachers have an important role in implementing e-learning (Singh, O’Donoghue \& Worton, 2004). Because e-learning has a basic impact in shaping higher education, and as a result of higher increased in demand of e-learning, therefore, higher education institutions should provide and create programs which meet the varies range of student's needs and expectations.

\subsection{Learning Motivation}

Learning motivation is an internal driving force that evokes, directs and maintains human behavior and claims that it plays an important role in learning process (Glynn, Aultman \& Owens, 2005). Student motivation to study is a major concern for many educational institutions (Masitsa, 2008) and motivation to learn largely contributes to the student interest and achievements (Keller, 1987). It was found that an interactive multimedia learning makes students interactively with the learning materials so that it makes the learning process becomes more interesting and students are motivated in the learning process (Teoh \& Neo, 2007)

By developing and using multimedia-based learning materials, teachers can deliver chemistry concepts as if it is real, resulting in high student motivation. The usage of multimedia can display message and animation simultaneously at real time, control the speed of student learning. Thus, the development and usage of instructional media is highly important in teaching and learning processes, because it could support teaching and learning activities and improve student motivation and can affect student outcomes.

Therefore, it is important for teachers to find out an effective strategy to motivate students in learning chemistry. One of the best alternatives to motivate students is to design and develop a good multimedia learning, so that chemistry concepts are well explained, as a result the learning process run effectively when all the influential capabilities in the process support each other in order to achieve educational goals.

By using multimedia, teachers can deliver subject matters in an innovative way and motivate students to study faster and effectively. Delivering subject matters using multiple media is considered more effective than a single medium (Shah \& Khan. 2015). An effective multimedia requires a variety of existing media characteristics incorporated into the learning content to deliver (Fitzgerald, Wilson \& Semrau, 1999; Nazir, Rizvi \& Pujeri, 2012). It was found that learning motivation affected student's learning achievement and learning outcomes 
(Tella, 2007).

\section{Methodology}

The population in this study was all of the students of the vocational public high school in grade XI, Percut Sei Tuan, Medan Indonesia and samples were selected as many as two classes which consisted of 72 students with a purposive sampling technique, and the two classes were classified into experimental and controlled groups. This research was based on the Development Research method of ADDIE model (Barab \& Squire, 2004; Brown, 1992; Collins, 1992; Reeves, Herrington \& Oliver, 2005;) which consisted of five phases, namely (A) analysis, (D) design, (D) development, (I) implementation and (E) evaluation as shown below:

\subsection{The First Step is Analysis Stage}

At this stage the main activity was to analyze whether we need or not to develop new learning media, analyze the feasibility and requirements for developing the learning media based on the 2013 Indonesian National curriculum.

\subsection{The Second Step is Design Stage}

In this stage we prepared the initial prototype or product design of the MAOL learning and validated. Validation was carried out by programming experts, colleagues or teachers at the same field of study.

\subsection{The third Step is Development Stage}

In this stage we developed off-line instructional multimedia using adobe flash player-9 based on the subjects and objectives and the 2013 Indonesian National Curriculum. It contained animations, examples and quizes. Afterward it was validated by experts of instructional media and expert of chemistry learning materials, by filling in the instructional media questionnaires based on content standard, display clarity, enlignment with the subject and programming complexity which has been set by the experts. The range of media eligibility criteria values can be seen in the Table 1.

Table 1. Feasibility criteria of the multimedia

\begin{tabular}{lll}
\hline No. & Average & Variable criteria \\
\hline 1 & $4,2-5,0$ & Very feasible \\
\hline 2 & $3,4-4,2$ & Feasible \\
\hline 3 & $2,6-3,4$ & Moderately feasible and no need revision \\
\hline 4 & $1,8-2,6$ & Relatively feasible some content revision \\
\hline 5 & $1,0-1,8$ & Not feasible and need total revision \\
\hline
\end{tabular}

\subsection{The Four Step is Implementation Stage}

The development stage is the stage in which the multimedia-based adobe flash-based off-line learning (MAOL) was tried out towards the experimental group in teaching acid and base solutions and the controlled group was taught the same subject using web-based adobe flash-based instruction online (WAFI) available in internet.

\subsection{The Last Step is Evaluation Stage}

This stage is used to measure student competencies in accordance with the learning objectives based on the 2013 Indonesian National curriculum.

\subsection{Data Collection}

Data collected was carried out by assessing students' mastery in the subject matter taught ie. acid and basic solutions using teacher made-test, distributing questionnaires, work-sheet assessment and document analysis. The test used to determine student outcomes based on the material developed, where the test was divided into two cathegories namely pretest and postest. Questionnaires were distributed to student samples in order to find out student motivation in the experimental and controlled groups. The assessment work-sheet distributed to the multimedia expertice in order to evaluate whether it needed to revice the learning multimedia products. Document analysis was used to complete parts the questionnaires in accordance with the stages of the research implementation. 


\section{Findings}

\subsection{Analysis Stages}

Before developing the MAOL instructional multimedia, it was analysed two WAFI learning about acid and base solutions for grade XI that were available in the internet and generally used in the selected school sample. The analysis used to determine whether the two WAFI learning were compatible with the 2013 Indonesian National curriculum.

Analysis of the WAFI was carried out by using assessment work-sheets. Analysis of the WAFI learning was performed by distributing questionnaires using Likert's scale to determine whether the multimedia X and Y were feasible and could be used in learning process in schools, it needed to take into account several indicators that must be met, such as how attractive the multimedia display, material coverage, questions, pictures and videos and quizzes or questions supported the multimedia. The development of the multimedia aims was to create a high quality of the off-line learning multimedia and highly feasible based on the 2013 Indonesian National Curriculum.

\subsection{Analysis of Multimedia X (the 1st Web-Based Multimedia Online)}

Analysing the $1^{\text {st }}$ WAFI learning based on display clarity, alignment with the subject matter, programming complexity is shown in Figure 1.

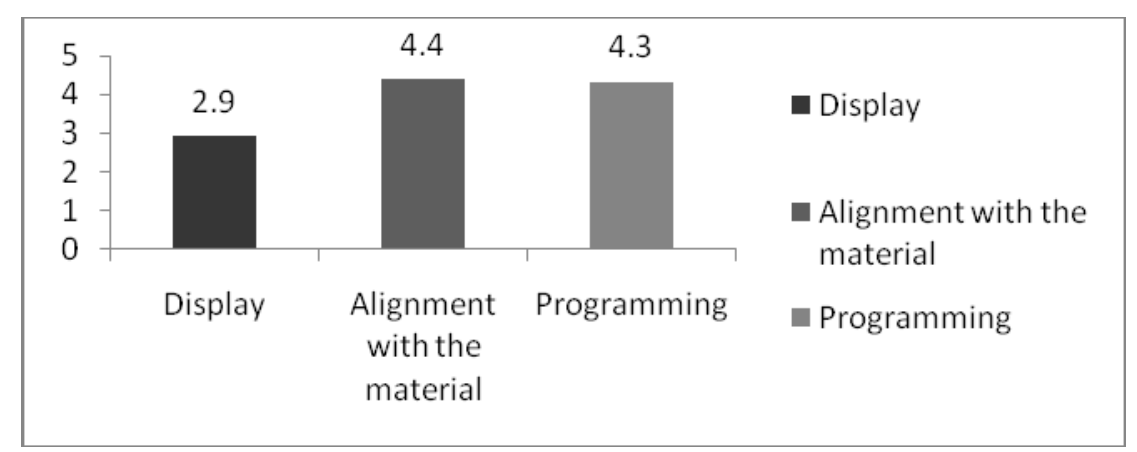

Figure 1. Feasibility test of the WAFI multimedia X

It is shown in Fig.1 that display clarity was relatively low (average value of 2.9), meanwhile alignment with the subject matter and programming complexity were considerably high with the average values of 4.4 and 4.3 respectively and it was considered that the multimedia was moderately highly feasible.

\subsection{Analysis of the Multimedia $Y$ (the $2^{\text {nd }}$ Web-Based Multimedia)}

The $2^{\text {nd }}$ WAFI learning was analyzed based on display clarity, alignment with the subject matter, programming complexity is shown in Figure 2.

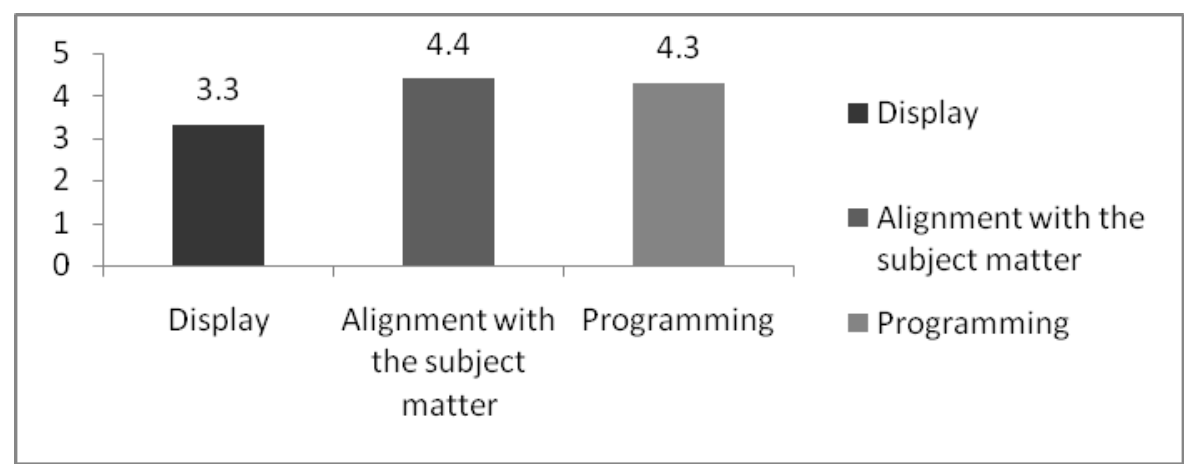

Figure 2. Feasibility test of the WAFI multimedia Y 
It is shown in Fig.2 that display clarity was relatively high (average value of 3.3), meanwhile alignment with the subject matter and programming complexity were considerably very high with the average values of 4.4 and 4.3 respectively and it is considered that the multimedia was moderately high feasible.

\subsection{Design Stage}

In the design stage, it was prepared the initial product (prototype) or product design. The design of the MAOL learning illustrated acid-base solutions, simulations, animations and quiz based on the 2013 Indonesian National Curriculm and presented as interactive instructional. The developed MAOL learning was made as good as possible to attract students' attention. The program was validated by expertice and colleagues or teachers from the same field of study.

\subsection{Development Stage}

In the development stage the MAOL learning was converted into an off-line softwere that suited to teaching-learning process. At this stage, it was designed to 1) create the main menu of the multimedia met learning objectives, 2) to create the main display attractive, exercises and other supporting menus as simple as possible 3) make interactive assessment and instance scores and 4) develop the interactive assessment in the form of games. The main display menu of the MAOL multimedia is shown in Figure 4 below.

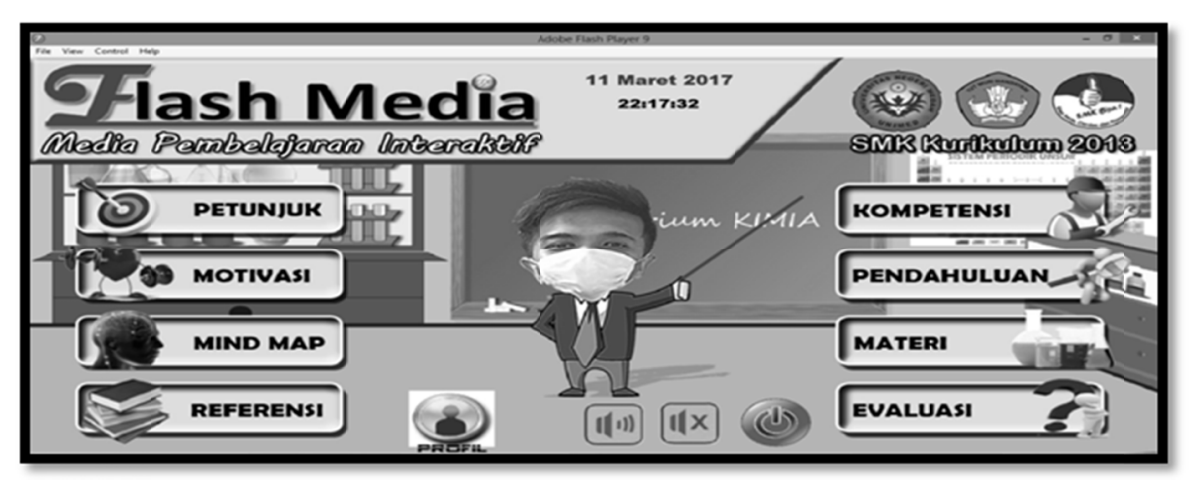

Figure 3. The main display menu of the MAOL learning

The assessment standard of the MAOL was carried out based on the validation instrument by the multimedia programming experts as well as the subject matter expertices concerning with acid and basic solutions and found that the MAOL was highly feasible, in which the display clarity, alignment with the subjects, and programming complexity values were 4.5., 4.8., and 4.3 respectively as shown in Figure 5.

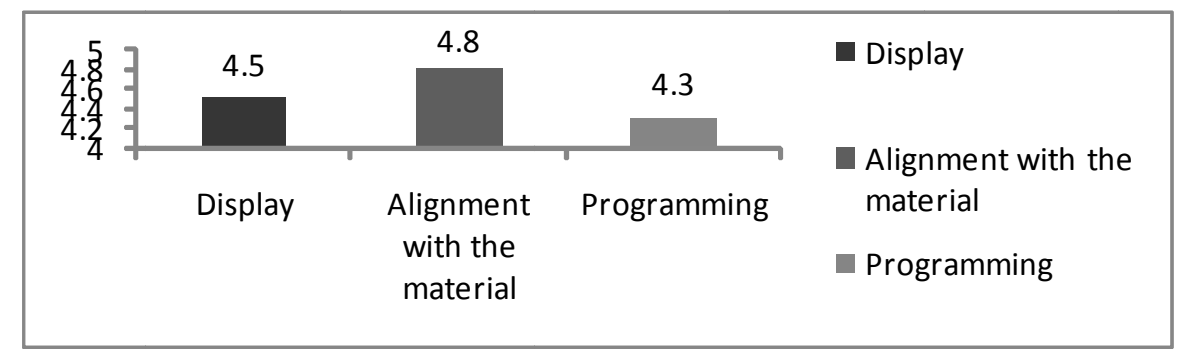

Figure 4. Feasibility Test of the MAOL Multimedia

\subsection{Implementation Stage}

Before conducting the research, the student samples i.e. the experimental and the controlled groups were tested about acid and basic solutions and the results showed in the following table 2. 
Table 2. Student pre-test scores

\begin{tabular}{lll}
\hline Sessions & $\begin{array}{l}\text { Groups } \\
\text { Experimental }\end{array}$ & Controlled \\
\hline Pre-test-1 & 60 & 58 \\
\hline Pre-test -2 & 63 & 61 \\
\hline Pre-test -3 & 645 & 63 \\
\hline Pre-test -4 & 66,5 & 65 \\
\hline Average & 63.5 & 61.75 \\
\hline
\end{tabular}

As shown in the Table 2 above that the average student score of the experimental group was relatively similar (63.6) to the controlled group (61.75). It means that the two groups had a relatively similar background knowledge about acid and basic solutions.

\subsection{Evaluation Stage}

The MAOL learning was tried out to the experimental group and found that the average value of the student achievements in the experimental group was relatively higher than the controlled group In this phase, students' competency was measured by conducting final assessments (post-test) and the results shown in Table 3 below.

Table 3. Student post-test scores

\begin{tabular}{ll}
\hline Groups & Post-test average values \\
\hline Controlled & 78,05 \\
\hline Experimental & 84,45 \\
\hline
\end{tabular}

The school determined the minimum passing grade was 75 and found that students in the controlled group have the average scores of 78.05 and it proved that there were a number of student grades fell below the minimum passing grade. However, the average score of the experimental group was 84.45 which showed that only a few of the students in the experiment group have grades below the minimum passing grade. It was assumed that the learning multimedia off-line developed has a great impact on the student outcomes, as shown in the Table 3 .

In addition, the learning motivation questionnaires were distributed to the experimental and controlled groups and found that the students in the experimental group were relatively high motivated than the controlled group (see Table 4).

Table 4. Learning motivation of the experimental and controlled groups

\begin{tabular}{lll}
\hline \multicolumn{1}{c}{ Class } & Controlled Group & Experimental Group \\
\hline HA & 6,50 & 8,32 \\
\hline $\mathrm{A}$ & 4,83 & 3,59 \\
\hline $\mathrm{S}$ & 0,67 & 0,08 \\
\hline $\mathrm{D}$ & 0,00 & 0,00 \\
\hline $\mathrm{HD}$ & 0,00 & 0,00 \\
\hline Average & 53,83 & 56,24 \\
\hline
\end{tabular}

$\mathrm{HA}=$ highly agree, $\mathrm{A}=$ agree, $\mathrm{S}=$ sometimes agree, $\mathrm{D}=$ disagree, $\mathrm{HD}=$ highly disagree.

After having pretest and pottest carried out, the results were analyzed with SPSS for windows, in order to find out student gain scores as shown in the Table 5 and 6 below. 
Table 5. Test between-subjects effects dependent variable: COMPUTE gain $=$ posttest - pretest

\begin{tabular}{llllll}
\hline Source & Type III Sum of Squares & df & Mean Square & F & Sig. \\
Experimental GRP & 3010.631 & 1 & 3010.631 & 46.140 & .000 \\
Error & 5466.035 & 70 & 84.076 & & \\
Total & 15703.000 & 72 & & & \\
\hline
\end{tabular}

Table 6. Means, Standard errors, and Confidence interval for the two groups

Dependent variable: COMPUTE gain $=$ posttest-pretest

\begin{tabular}{lllll}
\hline & & \multicolumn{3}{c}{$95 \%$ Confidence Interval } \\
Scores & & & Std. Error & \multicolumn{2}{c}{ Lower Bound } & Upper Bound \\
Experimental & -14.925 & 1.354 & -17.830 & -12.020 \\
Controlled & -1.474 & 1.392 & -3.459 & 1.301 \\
\hline
\end{tabular}

Student gain scores (posttest-pretest) were analyzed with analysis of variance using SPSS for windows, with experimental group (experimental vs. controlled) as the independent variable. The score was greater for student in the experimental group $(\mathrm{M}=-14.90, \mathrm{SE}=1.40)$ than for those in the controlled group $(\mathrm{M}=-1.50, \mathrm{SE}=1.40)$; $\mathrm{F}(1 / 72)=46.14, \rho<.005$. The $95 \%$ confidence interval for the experimental group mean ranges from -17.83 to -12.02. It does not include zero so the mean gain is different from zero. That is, there was significant student scores increased for participants in the experimental group. The $95 \%$ confidence interval for the controlled group mean ranges from -3.46 to 1.30 . It does include zero to the mean gain, so it is not different from zero. That is, there was no significant student score increased for participants in the control group.

Inspection of the $95 \%$ confidence intervals around each mean indicated that there was a significant increase in student scores for participants in the experimental group, and no increase in student score for participants in the controlled group.

\section{8 Correlation Coefficients}

The correlation coefficient test used to find out the degree of the relationship between learning motivation and student learning outcomes, and the results could be seen in Table 7 below:

Table 7. Pearson/s correlation coefficients

\begin{tabular}{llll}
\hline & & \multicolumn{2}{c}{ Learning motivation $\begin{array}{l}\text { Student } \\
\text { outcomes }\end{array}$} \\
Learning & Pearson Correlation & 1 & $.956^{* *}$ \\
motivation & Sig. (2-tailed) & & .000 \\
& $\mathrm{~N}$ & 72 & 72 \\
\multirow{4}{*}{ Student outcomes } & Pearson Correlation & $.956^{* *}$ & 1 \\
& Sig. (2-tailed) & .000 & \\
**. Correlation is significant at the 0.01 level (2-tailed). & \\
\hline
\end{tabular}

Based on the Pearson's correlation coefficient above, it was found that there was a significant correlation (Sig. $<0.05)$ between learning motivation $(\mathrm{X})$ and learning outcomes $(\mathrm{Y})(0.966)$. 


\section{Discussion}

This study demonstrated the significant relationship between the off-line multimedia and students' motivation therefore students are more likely to be more motivated when using the multimedia. Similar finding was also reported by Teoh \& Neo (2007). It is in line with Mayer's multimedia learning theory, which stated that the development and usage of multimedia can be used to motivate, stimulate and assist students in masterying the subject, since people processing verbal or words and visual materials or pictures separately, and a certain material can be processed at a certain time and as a result meaningful learning can be achieved when they engage in an appropriate cognitive learning process (Mayer 2002; Milkova, 2015; Al-Hariri \& Al-Hattami, 2017). It means that, teachers have important roles in the student outcomes. In addition it was found that the usage of multimedia as learning device contributed a great impact on student achievements which was also supported by Kalganova (2001). Furthermore, Anjarwati et al. (2016) investigated the usage of web-assisted lecture-based instruction systematically and reported that student motivation and achievement increased.

If students are highly motivated to learn, then they are highly likely to be more active and if they are actively involved, they are probably be able to achieve the learning objectives successfully (Keller, 1987; Kim \& Theodore, 2011), since learning motivation is an internal driving force that evokes, directs and maintains human behavior and it plays an important role in learning process (Keller, 1987; Glynn, Aultman \& Owens, 2005). Therefore, it would definitely be interesting to applying multimedia as a teaching aid in the instruction of students, since online discussion is proved to promote student centered learning. Therefore, it is reasonable to emphasize that online discussion could benefit the students and improve student performance (Mohelska \& Sokolova, 2014). Cheng \& Weng (2017) found that the use of multimedia has a positive influence on student's achievements. Furthermore, Amine, Benachaiba and Guimide (2012) also found that multimedia can be used to enhance student's motivation and learning achievement.

It means that the usage of multimedia in schools, should consider cousiously the points mention above in order to achieve teaching objectives appropriately because it makes the learning process more interesting and students are motivated in the learning process (Teoh \& Neo, 2007).

\section{Conclusion}

Based on the findings it was concluded that there was a significant impact of the off-line Multimedia-based learning towards student motivation and student outcomes, in which the multimedia is based on the National curriculum instead of the online multimedia based on general knowledges. The findings showed the importance of teachers' skills in integrating the Adobe flash softwares into the National Curriculum. Since teachers are the most powerfull elements in enchancing and motivating students to use the multidemia learning products. Many high school teachers are uncapable to develop a multimedia learning especially in chemistry, therefore they mainly depand on multimedia onlines. In addtidion, it was also found that there was a significant correlation between learning motivation and learning outcomes. Therefore, the off-line multimedia software could be linked to web-pages in order to distribute to students around Indonesia and helping them studying acid-base solutions and enhance student's learning motivation and learning achievements.

\section{1 Recommendation}

It is recommended that the developed multimedia software could be used to enchance student motivation and outcomes in learning chemistry particularly acid-base solutions in other public and private vocational high schools. It is also recommended to design another adobe flash-based multimedia based on the 2013 national curriculum in studying chemistry subjects, so the students in vocational high schools could take benefit from.

\section{2 Implications}

A common cause in educational development is the lack educational training in implementing a new technological strategy. This is mainly due to the lack of government interest in spending a great number of money to facilitate schools with new materials, laboratorium and new softwares that support educational developments such as adobe flash player-9, as a result, teachers would not be able to develop teaching strategy accordingly to the new technology development. Besides, the government has no great effort to prepare or to train teacher using multidemia as part of educational tools in enchancing virtual learning management system. Therefore, there is a great requirementsfor the teachers to develop learning material based on multimedia due to the fast development in internet around the globe. It is probably due to the fact the educational implementation can only be known after twenty five years of implementation, therefore, many politicians feels skeptic about the introduction of new technologies into educational system which needs a huge fund. 


\section{Acknowledgement}

We would like to thanks Prof. Dr. Bornok Sinaga, M.Pd for finishing tauch of this manuscript, and to Rector of the State University of Medan Prof. Dr. Syawal Gultom, M.Pd. for giving a great contribution to publish this article

\section{References}

Al-Hariri, M, T., \& Al-Hattami, A. A. (2017). Impact of students' use of technology on their learning achievements in physiology courses at the University of Dammam. Journal of Taibah University Medical Sciences, 12(1), 82-85.

Amine, B., Benachaiba, C., \& Guemide, B. (2012).Using Multimedia to Motivate Student's in EFL Classrooms: A Case Study of English Master's Students at Jijel University, Algeria. Malaysian Journal of Distance Education, 14(2), 63-81.

Anjarwati, D., Winarno, A., \& Churiyah, M. (2016). Improving learning Outcomes by developing instructional media-based adobe flash professional cs 5.5 on principles of business subject. IOSR Journal of Research \& Method in Education, 6(5), 01-06.

Anleigh, P. K., \& Thakar, K. (1997). Multimedia Systems Design. Upper Saddle River: Prentice Hall.

Anwariningsih, S. H., \& Ernawati, S. (2013). Development of interactive media for ICT learning at elementary school based on student self- learning. Journal of Education and Learning, 7(2), 121-128.

Barab, S., \& Squire, K. (2004). Design-based research: Putting a stake in the ground. The Journal of the Learning Sciences, 13(1), 1-14.

Bitner, N., \& Bitner, J. (2002). Integrating technology into the classroom: Eight keys to success. Journal of Technology and Teacher Education, 10(1), 95-100.

Brown, A. L. (1992). Design experiments: Theoretical and methodological challenges in creating complex interventions in classroom settings. Journal of the Learning Sciences, 2(1), 141-178.

Cheng, Y. H., \& Weng, C. W. (2017). Factors influence the digital media teaching of primary school teachers in a flipped class: A Taiwan case study. South African Journal of Education, 37(1), 1-12.

Collins, A. (1992). Towards a design sciences of education. In Scanlon, E., \& O’Shea, T. (Eds.), New Directions in Educational Technology, pp. 15-22.

Dale, E. (1963). Audio Visual Methods in Teaching. New York: Holt, Rinehart and Winston.

Fitzgerald, G. E., Wilson, B., \& Semrau, L. P. (1996). Designing Effective Multimedia Programs to Enhance Teacher Problem Solving Skills and Cognitive Flexibility. Proceedings of Ed-Media, 96, 1-7.

Garcia, R. R., Quiros, J. S., Santos, R. G., Gonzalez, S. M., \& Fernanz, S. M. (2007).Interactive multimedia animation with macromedia flash in descriptive geometry teaching. Journal Elsevier Computers \& Education, 49, 615-639.

Glynn, S. M., Aultman, L. P., \& Owens, A. M. (2005). Motivation to learn in general education programs. The Journal of General Education, 54(2), 150-170.

Jantjies, M., \& Joy, M. (2016). Lessons learnt from teachers' perspectives on mobile learning in South Africa with cultural and linguistic constraints. South African Journal of Education, 36(3), 1-10.

Keller, J. M. (1987). Development and use arcs model of instructional design. Jounal of Instructional Development, 10(2), 2-10.

Kim, K. J., \& Fric, T. W. (2011). Changes in Student Motivation during Online Learning. Journal of Educational Computing Research, 44, 1-23.

Kozman, R. B., \& Russell, J. (1997). Multimedia and understanding: expert and novice responses to different representations of chemical phenomena. Journal of Research in Sciences Teaching, 34(9), 949-968.

Masitsa, G. M. (2008). Tracing the development of poor student motivation and performance in township secondary schools. Journal Africa Education Review, 5(1), 84-108.

Mayer, R. E. (2002). Multimedia learning. Psychology of Learning and Motivation, 41, 85-139.

Milkova, E. (2015). Multimedia application for educational purposes. Development of Algorithmic Thinking, Applied Computing and Informatics, 11, 76-88. 
Mohelska, H., \& Sokolova, M. (2014). Effectiveness of Using E-Learning for Business Disciplines: The Case of Introductory Management Course. Ekonomie A Management, 17(1), 82-92.

Nazir, M. I. J., Rizvi, A. H., \& Pujeri, R. V. (2012). Skill development in Multimedia Based Learning Environment in Higher Education: An Operational Model. International Journal of Information and Communication Technology Research, 2(11), 820-828.

Niaz, M., \& Rodriguez, M. A. (2000).Teaching chemistry as rhetoric of conclusions or heuristic principles-a history and philoshopy of science perspective. Chemistry Education: Research and Practice in Europe, 1(3), 315-322.

Othman, J., Treagust, D. F., \& Chandrasegaran, A. L. (2008).An investigation into the relationship between student's conception of the particulate nature of matter and their understanding of chemical bonding. International Journal of Science Education, 30(11), 1531-1550.

Ramnarain, U. (2011). Teachers' use of questioning in supporting learners doing science investigations. South African Journal of Education, 31(1), 91-101.

Reeves, T. C., Herrington, J., \& Oliver, R. (2005). Design research: A socially responsible approach to instructional technology research in higher education. Journal of Computing in Higher Education, 16(2), 97-116.

Salim, K., \& Tiawa, D. H. (2014).Development of media-based learning animation for mathematics course in electrical engineering. International Journal of Advanced Research in Computer and Communication Engineering, 3(10), 8332-8336.

Salim, K., \& Tiawa, D. H. (2014). Development of media-based learning animation for mathematics course in electrical engineering, University Riau Kepulauan. International Journal of Advanced Research in Computer and Communication Engineering, 3(10), 8332-8336.

Shah, I., \& Khan, M. (2015). Impact of Multimedia-aided Teaching on Students' Academic Achievement and Attitude at Elementary Level. US-China Education Review A, 5(5), 349-360.

Singh, G., O'Donoghue, J., \& Worton, H. (2004). A Study into the Effects of E-learning on Higher Education. Journal of University Teaching and Learning Practice, 3, 14-24.

Skourdoumbis, A. (2014). Teacher effectiveness: making the difference to student achievement?. British Journal of Educational Studies, 62(2), 111-126.

Sylvestre, M., Haiyan, H., \& Yiyi, Z. (2016). Information communication technology policy and public primary schools' efficiency in Rwanda. South African Journal of Education, 38(1), 1-10.

Tella, A. (2007). The Impact of Motivation on Student's Academic Achievement and Learning Outcomes in Mathematics among Secondary School Students in Nigeria. Eurasia Journal of Mathematics, Science \& Technology Education, 3(2), 149-156.

Teoh, B. S. P., \& Neo, T. K. (2007). Interactive multimedia learning: student's attitudes and learning impact in an animation course. The Turkish Online Journal of Educational Technology - TOJET, 6(4), 28-37.

Trumbull, D. J., Scarano, G., \& Bonney, R. (2006). Relations among Two Teachers' Practices and Beliefs, Conceptualizations of the Nature of Science, and their Implementation of Student Independent Inquiry Projects. International Journal of Science Education, 28, 1717-1750.

$\mathrm{Wu}, \mathrm{H}$. K. (2003). Linking the microscopic view of chemistry to real lifeexperiences: intertextuality in a high-school science classroom. Science Education, 87(3), 868-891.

Ziad, H. (2016). Integration Computers in the Classroom: Barriers and Teachers' Attitudes. International Journal of Instruction, 9(1), 65-78.

\section{Copyrights}

Copyright for this article is retained by the author(s), with first publication rights granted to the journal.

This is an open-access article distributed under the terms and conditions of the Creative Commons Attribution license (http://creativecommons.org/licenses/by/4.0/). 